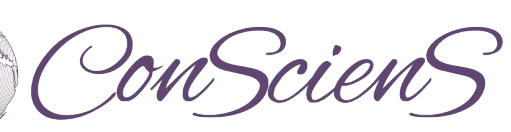

DOI: $10.5281 /$ zenodo.4542360

\title{
Alleviating COVID-19 Inequality
}

\author{
Julia M. Puaschunder ${ }^{1,2}$ \\ ${ }^{1}$ The New School, Department of Economics, School of Public Engagement, New York, NY 10003, \\ USA,Julia.Puaschunder@newschool.edu,www.juliampuaschunder.com \\ ${ }^{2}$ Columbia University, Graduate School of Arts and Sciences, Julia.Puaschunder@columbia.edu, \\ http://blogs.cuit.columbia.edu/jmp2265
}

\begin{abstract}
This paper detects and offers solutions to alleviate COVID-19 induced inequality. The COVID-19 external shock now clearly created economic disparity between nations, industries and societal groups. This paper discusses rising inequality trends in finance, healthcare and digitalization exacerbated during the global COVID pandemic. It then discusses the most novel and cutting-edge innovations in bridging the finance-world and real economy inequality gap, fostering digitalization advancements and common goods oriented access to affordable healthcare but also equality in connectivity and tech-skills development to overcome unforeseen inequality in the shadow of COVID-19.
\end{abstract}

KEYWORDS: Banking, Connectivity, Consumption, Coronavirus, COVID-19, Digitalization, Finance, Healthcare, Medical care, Real economy, Social volatility, Socio-Economics

\section{COVID-19 inequality}

The COVID-19 external shock now clearly created economic disparity between nations, industries and societal groups. The Union Bank of Switzerland (UBS) currently describes the largest economic gap between world economies for at least 40 years (The Economist October 8, $2020 \mathrm{a}, \mathrm{b}, \mathrm{c})$. In contrast to earlier economic turmoil stemming from system-inherent crises creating liquidity constraints, the external COVID shock caused "social volatility" - a collectively depressed mood that largely dampened consumption. The difference to previous systemic recessions becomes apparent in the rapid recovery of well-managed financial funds - for example, the S\&P 500 recovered $50 \%$ of its pre-COVID value within the first three months after the crisis and reached an all-time high in August 2020. Deutsche Bank recorded rising earnings after the onset of Coronavirus crisis in Europe, especially the investment bank branch of $43 \%$ or 2.4 billion euros. The clear distinction between COVID-19 profit and loss industries made it possible for today's highly flexible financial world to quickly exchange weakened market segments - such as oil, public transport and aviation, face-to-face service sectors such as international hospitality and gastronomy - with above-average market options - such as pharmaceutical companies and emergency medical devices for healthcare, digital technologies, fintech, artificial intelligence and big data analytics industries, online retail, automotive and interior design industries.

Inequality has increased in society since the 1990s as a result of the wave of US financial market deregulation (Piketty 2014). The financial world performance began to diverge massively from the real economy in 2008/09 and experienced the greatest divergence so far with the Coronavirus crisis that widened the gap between top performance of financial markets and negative fallout in the real economy (The Economist, October 10, 2020a, b, c).

The strong contrasts between COVID-19 winners and losers as well as the deep gap between strongly positive financial market developments and the negative performance of the real economy induced by lockdowns, which is currently exposing the real economy to a wave of private bankruptcies and liquidity bottlenecks, therefore call on governments around the world to reboot financial markets to return to be a service industry - to serve the real economy (Reddy 2020e).

Government bailout packages are likely to be financed over the long term by the historically-lowest, never-so-long-low key interest rates. Low key interest rates will continue 
to allow the capital market to flourish. But this is based on the cost of a weakening of the potential of the interest rate as a monetary policy tool, which the economist John Maynard Keynes (1936/2003) already described as a "liquidity trap." The low interest rate policy brings along long-term external financing of past ideas, which impairs the flexibility of investors to finance future-oriented innovations and may hold back societal progress. Low interest rates on savings accounts in the real economy keep people trapped in the debt financing of past dreams (Arora 2020). Household debt traps are causing massive psychosocial burdens, a so-called 'deaths of despair' trend is already noticed in the US for mid-career death spikes induced by alcoholism, drug use and suicide (Case \& Deaton 2020).

In the future, social friction is expected due to the strong polarization of financial profits sponsored by low key interest rate policy. The flexible substitutability of financial fund components in the exchange of loss segments for winning industries increases financial market profits, but at the same time reduces liquidity capacity and sustainability survival of small and medium-sized enterprises. In this sense, the generally low interest rate creates a situation that the financial world lives at the expense of the real economy.

Taxing the COVID-profit industries, especially digitization winners, could create fiscal space for redistributing some of the economic gains to industries that clearly lose from COVID-19. Taxation of digitalized economic growth during our forced digitalization disruption could provide the necessary redistribution funds to back the liquidity-dried real economy. Governments can also bring back the financial world in the service of improving and stabilizing the real economy in a stricter separation between investment and consumer banks, which already began in the course of the regulations following the 2008/09 recession. Central bank could offer diversified interest rates. Low key interest rate for driving innovation and economic growth in the financial sector that refunds higher interest rates for the real economy savings for consumers in order to avert psychosocial friction from individual overindebtedness in households.

Online currencies, such as the currently planned European Central Bank digital currency, could help a transparent use of the currency over time to strictly divert interest rate profits and avoid arbitrage or interest rate swops.

Mutual collateral insurance between the financial world and the real economy would also be possible in order to spread risk.

Bonds have also been discussed to enable innovations while repayments should be redistributed to the real economy. Bonds have been used throughout history to finance longterm strategies with unknown outcome (Puaschunder 2013, 2015).

In addition, could banks be encouraged to use the current profits for future large-scale investments that add societal long-term value. For example, large construction projects but also innovation in research and development are valuable macroeconomic multipliers that can benefit society as a whole in the short and long term (Epstein 2020; Keynes 1936/2003). Governments and intergovernmental bodies, like the European Union, have the long-term vision and financial freedom to operate on deficits but also the regulatory means to enact large-scale redistribution and long-term wealth creation in grand investments for the future. The COVID-19 pandemic could become a major reset offering also exciting opportunities and long-lasting positive societal advancements that come out of the crisis such as preventive medical care, reconnection with nature but also digitalization.

On an interconnected globe with a highly mobile 21 st century population and a most contagious virus, common health and well-being are as internationally-interdependent as never before in the history of modern humankind. The endeavor of a commonly healthy world with attention for precaution against pandemics is challenged by nowadays unprecedentedlyblatant healthcare inequality around the world.

Access to affordable quality medicine and precautionary prevention of widespread diseases depend on economic prosperity and freedom from corruption. Modern healthcare 
being technologically advanced also requires digitalization and innovation market financialization for modern preventive and precautionary medical care.

In macroeconomic modelling, my empirical research brought forward four indices shedding light on health inequality in the 21 st digital century. Internet connectivity and high Gross Domestic Product are likely to lead on AI-driven big data insights for pandemic prevention. On these dimensions, Europe, Asia and North America have optimal global healthcare leadership potential. International data on healthcare standards in relation to digitalization, economic prosperity, freedom from corruption and innovation market financialization revealed that Europe and North America feature excellent starting positions on economic productivity, digitalized healthcare and relatively low levels of corruption.

Already before the outbreak of the pandemic, Artificial Intelligence, algorithms, robotics and big data entered healthcare with booming health self-tracking devices and preventive medical care enhanced by big data insights.

COVID peaked attention for hygiene, pharmaceuticals and emergency medicine. COVID-19 healthcare apps now estimate individual contagion risks and derive large-scale health trends from big data. Digitalized healthcare heightens demand for privacy protection of vulnerable patients and anti-discrimination based on health status. Bluetooth-cartography of medical devices helps overcome bottlenecks and prevents fraud while protecting privacy. Telemedicine cures remotely all over the world.

With pre-existing prevalence, such as obesity and diabetes, but also the immune system influencing the COVID disease trajectory, preventive care and whole-rounded lifestyles gained unprecedented attention. Europe benefits from highest standards on public preventive medical care, while the United States has the most prosperous market financialization to advance medical innovations and Asia appears to have the most sophisticated data tracking software in place.

As future predictions, equal access to the internet and affordable preventive healthcare around the world would help as future pandemic precaution. With the current vaccination efforts around the world questions arise in the interplay of law and economics. How far should intellectual property laws should be enforced to ensure the highest pharmaceutical sector margins remain to uphold excellence and innovation driven by competition. A COVID19 vaccination should be offered to the entire world to reach general immunity quickly and eradicate COVID-19. Thereby a legal strategy such as outlined by the Trade-Related Aspects of Intellectual Property Rights, or TRIPS agreement, of the General Agreement of Tariffs and Trade has been brought forward by the WTO. Since the 1990s the TRIPS agreement granted access to affordable medicine to low income countries while protecting patent rights in the developed world to ensure market remuneration for medical innovation in order to uphold high quality of medical services.

As a future prospect, digitalization and big data insights for the healthcare sector appears as long-term pandemic prevention plan. In the healthcare sector, the EU has a competitive edge as for a historically-grown wealth of data of a homogenous population as European citizens pay for free universal healthcare by automatic provision of data. Within Europe, potential exists to bundle the largest and most refined historic datasets on health of 500 million European citizens in order to derive inferences for prevalences and tailored personal medical care. In the age of information, big data has become the new untaxed wealth generation means. Novel computational advancements can now retrieve medical insights from patient data that can be capitalized, especially for preventive medical care.

Due to a highly-skilled population, the European continent is a technological innovation leader and picks up technological advancements around the world quickly and efficiently. Europe also hosts a major part of historically-grown pharmaceutical agencies that are relatively independent of market actors - in the US, for instance, big data insights are 
regulated by the Federal Trade Commission (FTC) and the Federal Communications Commission (FCC), two agencies that are more market oriented.

The US medical market is more fractionated into public and private sector health and features a more market-focused approach. Europe has a post-war history of stressing ethical considerations in market-driven innovations. A European track-record exists for putting a human face onto capitalism. Innovation is ennobled with an ethical imperative focus - for instance, using more precautionary standards in releasing drugs.

In the corporate sector, the German Präventionsgesetz or Prevention Act ${ }^{1}$ grants governmental funding to corporations for preventive self-care and team learning of healthy lifestyles. As never before in the history of industrialization, employers now watch out for creating a healthy workplace environment with hygienic interaction, constantly tracking workforce safety and requiring health self- and group monitoring. Home office flexibility outsources workplace health risks, as do newly-erected office glass walls in interior designs. The Austrian Sozialpartnerschaft embraces stakeholder decision making in shaping an overall healthy workplace environment. As for healthcare evolutions, anti-depression and anti-obesity or anxiety control should create a collective environment for personal social change, involving the larger social network (Berlant 2011). The governmental, corporate, and personal responsibility could target at providing oversight of the public good in deference to corporations.

Future advancements lie in bundling information for pandemic prevention and medical resource tracking. In order to enable a big data capitalization coupled with upholding highest ethical standards, the European Union should foster a fifth trade freedom of data to bundle AI and big data gains large scale. While big data is primarily used in the US to offer more targeted consumerism, Europe should aim for building a data stock to retrieve information for preventive care leading the world with ethical imperatives in big data insight-driven medicine. On the European level, a EU fifth trade freedom of data could set positive market incentives for sharing information, but also provide big data privacy protection and legal antidiscrimination means against misuse of sensitive data - such as stigmatization - of vulnerable patients.

Data insights should only be used for the benefit of people but not be turned against human beings. A stakeholder survey conducted in November 2019 revealed that risks in the use of big data insights in healthcare include data misuse and leakage leading to privacy infringements, as well as biases and errors (Puaschunder 2020). Big data insights open gates for health care pricing, stigmatization, social stratification, discrimination and manipulation.

Big data in the healthcare sector should only be used with caution and targeted particular information release to avoid discrimination. For instance, only anonymized data slices should be made available to the public in order to avoid stigmatization, gentrification and discrimination based on predictable prevalences within population groups or certain districts.

Data protection through technological advancement, self-determined privacy attention through education as well as discrimination alleviation through taxation of data transfer values are recommended. Taxation of data transfer revenues will grant the fiscal space to offset losses and the social costs of market distortions caused by new technologies taking over human tasks and entering the workforce in the medical marketplace.

When it comes to the currently exacerbated online digital disruption in the wake of COVID-19, less discussed are currently opening inequalities based on international time zones that create natural barriers. Natural day and night time conditions currently implicitly

\footnotetext{
${ }^{1}$ Gesetz zur Stärkung der Gesundheitsförderung und der Prävention (Präventionsgesetz - PrävG) vom 17. Juli 2015, BGBI $2015,1 / 31$.
} 
connect or separate continents. Online knowledge transfer is favored due to the time harmony. Common daytimes flourish exchange, while a day-night divide disconnects us for real-time exchange.

Direct exchange in work relations, telemedicine or innovation ideas exchange are facilitated within a time zone. If the digitalized exchange persists, this may create new timezone bundles. North and South America, Europe-Africa and Central Asia-Southeast AsiaAustralia are emerging as new time-harmonious clusters, which operate in the same time zone. This may finally improve the north-south divide by facilitating the exchange of information and fostering common projects - such as virtual conferences and subsidiaries. Opening the online window to a different, better world, however, will likely increase already rising mobility trends. Europe will be pegged to Africa, where digitalization ranks lowest and European officials will likely face the predicament between infrastructure development in Africa for the sake of rising migration from Africa and instigating brain drain.

Concrete wellness and healthcare trends are emerging in the contemporary pandemic. COVID-19 triggered a de-urbanization in the US - a trend to move to environmentallypleasant surroundings. Given the contagion risk in crowded metropolitan areas and air purification being challenged in city skyscrapers with closed ventilation and elevators, corporate headquarters currently move to remote work or suburbs. Retail shifted online to lower fixed cost of real estate and health risks. Hygiene and health leveraged into core business of contemporary cityscaping - as visible in the New York public transport cleanup and consumer trends to own personal cars or bikes. Art and culture events scaled down to more rural communities or are currently re-curated for social distanced performances or even are staged in virtual luxury worlds. Gastronomy order-ins and shared virtual eating experiences are socially-distanced service sector innovations. The sharing economy started offering workspace closer to nature.

Moving to cheaper suburbs now allows a remote workforce to build wellness cocoons with attention for healthy living embedded in nature. The environment is also represented in biophilic architecture trends that resembles nature. Or fungus clothing designed as carbonnegative organic alternative to fast fashion. Hygienic antibacterial surfaces for cleanability and technologically-enhanced kitchens are booming. With precise online retailing and people spending more time at home, minimalism is trending as people are getting rid of unnecessary items at home.

The de-urbanization is yet not a ruralization, as people are not giving up luxuries of metropolitan areas, such as exchange of goods, services and ideas in highly specialized markets with diverse market actors. Today's cosmopolitan luxury shifted into virtual online spaces as COVID-19 has also perpetuated the online tech world. Physically distant, we came closer digitally than ever before. Worldwide data traffic exploded on a flat digital globe. An online multitasking workforce gained global reach, while technology reduced bureaucracy. Digitalization kicked in all industries.

As North American universities currently face high revenue losses from international students staying away and closed campus housing, universities are exploring hybrid education in larger international network consortia. Students from all over the world could thereby flexibly take courses in large international education hubs with participating institutions being far spread out over the world. Without relocation costs and visa requirements, students will also be free to study longer. Education of the future could thus become truly global, individually-specialized and life-long. Global access to online education could become an international development transformation game changer. Overall expected price adjustments for education in the United States may lift the education debt burden in the US that has already curbed large-scale consumption of the generation internship since the beginning of the millennium. For Europe there is the potential to partner with North American elite institutions or create multi-lingual European consortia to bundle excellence. 
With the digitalization disruption, however, come along novel inequalities. Inequality in internet connectivity, tech-skills and digitalization-affinity, leverages AI-humancompatibility as competitive advantage. Digital online working conditions that make individual living conditions transparent emphasize social hierarchies in our educational and work-related interactions.

On a global scale, problems arise from a dominance of digital innovations and online communication tools being centered in the United States, which imposes a data deficit, revenue losses and problems to enforce European privacy protection. The new use of digitization in the healthcare sector increases the demand for online data protection for particularly vulnerable patient groups and anti-discrimination in big data derived inferences.

Taxing digital economies could create the fiscal space to offset technology disruption fallouts and ensure education and trainings honing mindful use of new technologies. Healthy and informed access to new media needs to address the dilemma between the individual benefit from information exchange online versus the human dignity of privacy on the Internet. In the digital age, we cannot estimate what effects the sharing of private information, trancheby-tranche, over time has in merging, in relation to large amounts of data and over time.

The anonymous participation in new virtual realities currently also brings with it completely new problems such as cyber crime, hate postings and social censorship by the online masses. Governments and traditional media have lost control of online censorship in the digital age.

In an attempt to uphold ethics and responsibility in virtual global online worlds that are currently open to us on the Internet, the European Union has launched the General Data Protection Regulation, GDPR, and taxation attempts of online revenue. European legal scholars and activists are defining legal rights of individuals to be forgotten online and the dignity of conscientious data protection and e-privacy.

\section{References}

Arora, R. 2020. "Which companies did well during the Coronavirus pandemic?" Forbes, June 30, 2020.

Berlant L. G. 2011. Cruel optimism. Durham, NC: Duke University Press.

Case, A. \& Deaton, A. 2020. Death of despair and the future of capitalism. Princeton, NJ: Princeton University Press.

Epstein, G. 2020. The Coronavirus consensus: “Spend, Spend, Spend.” Dollar \& Sense: Real World Economics, March 2020. Retrieved at http://dollarsandsense.org/archives/2020/0320epstein--spend.html.

Keynes, J.M. 1936/2003. The general theory of employment, interest and money. Cambridge, MA: Harvard University Press.

Piketty, Th. 2014. Capital in the twenty-first century. Cambridge, MA: Harvard University Press.

Puaschunder, J.M. 2013. "Ethical investing and socially responsible investing." In Baker K. H. \& Ricciardi, V. (Eds.), Investor Behavior, pp. 515-532. New York, NY: John Wiley \& Sons Finance Series.

Puaschunder, J.M. 2015. "When investors care about politics: A meta-synthesis of political divestiture studies on the capital flight from South Africa during Apartheid." Business, Peace and Sustainable Development, 5(24): 29-52.

Puaschunder, J.M. 2020. Big data, algorithms and health data. Report on behalf of the European Liberal Forum of the European Parliament. Brussels and Vienna, European Union.

Reddy, S. 2020e. "Lockdowns are costing us: It's time to be smart." Barron's, May 23, 2020. Retrieved at https://www.barrons.com/articles/lockdowns-are-costing-us-its-time-to-be-smart-51590193324.

The Economist 2020a. "Changing places." October 8, 2020.

The Economist 2020b. "The pandemic has caused the world's economies to diverge." October 8, 2020.

The Economist 2020c. "The peril and the promise." October 8, 2020. 